\title{
Coppicing improves the growth response of short-rotation hybrid aspen to elevated atmospheric humidity
}

\author{
Arvo Tullus $^{\mathrm{a}, *}$, Katrin Rosenvald ${ }^{\mathrm{a}}$, Reimo Lutter ${ }^{\mathrm{b}, \mathrm{c}}$, Ants Kaasik ${ }^{\mathrm{a}}$, Priit Kupper ${ }^{\mathrm{a}}$, Arne Sellin ${ }^{\mathrm{a}}$ \\ ${ }^{a}$ Institute of Ecology and Earth Sciences, University of Tartu, Lai 40, Tartu 51005, Estonia \\ ${ }^{\mathrm{b}}$ Institute of Forestry and Rural Engineering, Estonian University of Life Sciences, Kreutzwaldi 5, Tartu 51006, Estonia \\ ${ }^{\mathrm{c}}$ Department of Forest Ecology and Management, Swedish University of Agricultural Sciences, Skogsmarksgränd 17, Umeå SE-90183, Sweden
}

\section{A R T I C L E I N F O}

\section{Keywords:}

Aspen coppice

Climate change

Forest acclimation

Intraspecific competition

Populus

Stand structure

\begin{abstract}
A B S T R A C T
Aspens are fast-growing clonal trees with a wide circumboreal distribution range, suitable for the production of pulp and bioenergy. The adaptability of aspen short-rotation coppice systems to climate change has rarely been investigated. For a large part of aspens' northern range, climate models predict an increase in precipitation and, consequently, in atmospheric humidity. Our aim was to clarify the long-term effect of elevated air humidity on vegetative reproduction capacity and dynamics of above-ground growth and size structure in aspen stands. We analysed tree growth data from two consecutive 6-year rotations (a planted and a coppice generation) in experimental short-rotation hybrid aspen (Populus tremula L. $\times$ P. tremuloides Michx.) stands in the Free Air Humidity Manipulation (FAHM) experiment in Estonia. In three plots, mean relative air humidity was elevated by $7 \%$ and three plots were controls. Across two rotation periods, the humidification effect on tree height and/or stem basal area increment was year-dependent $(p<0.001)$ : negative in 4 years, positive also in 4 years and non-significant in 3 years. Mean basal area of humidified $\left(11.6 \pm 0.8 \mathrm{~cm}^{2}\right)$ and control trees $\left(15.0 \pm 1.0 \mathrm{~cm}^{2}\right)$ differed significantly $(p=0.035)$ at the end of the first but not the second rotation period $\left(9.3 \pm 0.9 \mathrm{~cm}^{2}\right.$ and $9.3 \pm 1.2 \mathrm{~cm}^{2}$, respectively). Average growth differences levelled out already in the beginning of the second rotation, suggesting that some root-level acclimation must have taken place. The annual size-growth relationships (SGR) indicated a more size-symmetric growth in humidified (SGR $=1.00 \pm 0.05$ ) and a size-asymmetric growth (SGR $=1.12 \pm 0.04)$ in control stands, implying a greater role of root-competition in humidified stands. In humidified stands, the growth of re-sprouting trees was more strongly determined by parent tree size, indicating a stronger carry-over of size hierarchy. The tree height diversity fluctuated more in control stands, where mortality was higher, especially after dry years. To summarise, short- and long-term responses of hybrid aspen to elevated air humidity varied, emphasizing the importance of long-term climate manipulations with trees. Generally, hybrid aspen short-rotation coppice forests showed promising acclimation capacity with future more humid climate predicted for northern latitudes.
\end{abstract}

\section{Introduction}

The two aspen species European (or Eurasian) aspen (Populus tremula L.) and North American quaking aspen (P. tremuloides Michx.) are among the most wide-spread tree species in Eurasia and Northern America, respectively (Dickmann and Kuzovkina, 2014). Aspens are recognized for high biodiversity value and considered keystone species (Kouki et al., 2004; Latva-Karjanmaa et al., 2007) but their economic value for forest industry has traditionally been modest. This has changed during the past few decades when the use of aspen and aspen hybrids for the production of pulp- and energy wood has expanded considerably, especially in northern temperate, hemiboreal and boreal regions (David et al., 2001; Tullus et al., 2012a; Rytter and Rytter, 2017; Hytönen, 2018).

Although aspens can regenerate by seed (Worrell et al., 1999; Landhäusser et al., 2019), re-sprouting from root and stump sprouts (also called suckers) is their major reproductive strategy after natural disturbance or clearcutting (Worrell, 1995; Frey et al., 2003). The sprouts develop from preformed or adventitious shoot primordia (sucker buds) formed on roots, whereas the suckering-controlling signal has apparently multiple endogenous sources, including accumulation of cytokinins and other root-derived compounds and a reduction in the inflow of auxins and other shoot-derived growth regulators (Wan et al., 2006). Aspen coppice generation can be highly vigorous at a young age

\footnotetext{
* Corresponding author.

E-mail address: arvo.tullus@ut.ee (A. Tullus).
} 
(Liesebach et al., 1999) because root and stump sprouts can rely on the root systems of their parent trees.

As a negative consequence of climate change, aspens have suffered from decline mainly in drought-predisposed regions of North America (Rehfeldt et al., 2009; Worrall et al., 2013). The impact of climate change on aspen suckering is difficult to predict because there are several gaps in the knowledge about factors controlling suckering (Frey et al., 2003). To our knowledge, aspen vegetative regeneration has rarely been included in climate manipulations, and only short-term responses of re-sprouting aspen to elevated $\mathrm{O}_{3}$ levels have been reported (Darbah et al., 2011). There are not many climate manipulations that follow stand dynamics through several consecutive rotations also with other coppicing trees such as poplars (Liberloo et al., 2006; Lagomarsino et al., 2013). In poplars, enhanced growth response to elevated $\mathrm{CO}_{2}$ levels persisted across two rotation periods (Liberloo et al., 2006).

The long-term responses of aspen regeneration to increasing precipitation and relative air humidity - a climate trend predicted for higher latitudes of the Northern Hemisphere (Kont et al., 2003; Lindner et al., 2014; IPCC, 2014; Sellin et al., 2017a; Oksanen et al., 2019), which overlaps with almost half of the aspen natural range - are not known. Day-time relative air humidity in forests is usually higher under canopy than in gaps and open landscapes (Aussenac, 2000; DaviesColley et al., 2000; Latif and Blackburn, 2010; Valladares et al., 2016). As this difference depends on soil water availability (von Arx et al., 2012), then it will be amplified by increasing amount and frequency of precipitation. In the colder climate of Northern Europe, the artificial cross between $P$. tremula and $P$. tremuloides (hybrid aspen) has proven to be a highly productive hardwood, suitable for short-rotation forestry (Tullus et al., 2012a; Rytter and Rytter, 2017, Hytönen, 2018). Hybrid aspen is included as a test species in the unique FAHM experiment established in the hemiboreal forest zone, where the forest ecosystem performance under artificially elevated air humidity is studied (Kupper et al., 2011). During the first 6-year study period, several stress responses were observed in planted hybrid aspens under elevated humidity, including reductions in transpiration, nutrient uptake and above-ground growth (Tullus et al., 2012b, 2017; Rosenvald et al., 2014) and enhanced production of foliar secondary metabolites (Lihavainen et al., 2016; Sellin et al., 2017a).

The responses of trees to climate change depend on the competitive status of trees for aspens (McDonald et al 2002; Tullus et al., 2017) and other poplars (Calfapietra et al., 2003), suggesting that stand structural development is likely also affected by future climatic conditions. Stand structural diversity is a crucial indicator of overall habitat diversity offered by the stand (McElhinny et al., 2005; Barbeito et al., 2009), including by young planted stands and coppice forests (Humphrey et al., 1999; Sullivan et al., 2001), whereas in coppicing systems, the size hierarchy of trees can be maintained through multiple rotations (Edelfeldt et al., 2018).

The main aim of this study was to analyse the long-term impact of elevated air humidity on growth and size structure of aspen stands across two consecutive rotation periods. The specific aims were: (i) to clarify the effect of elevated air humidity on sprout number, growth, survival and size structure of re-sprouting hybrid aspens, (ii) to compare the tree responses to elevated humidity between the first (planted) and the second (coppiced) 6-year rotation and (iii) to clarify the effect of parent tree size on the growth of stump sprouts.

We hypothesised that: (i) growth stress induced by elevated humidity will persist in the re-sprouting second rotation, (ii) stand structural development in the second generation will be affected by carry-over of size hierarchy from the first rotation.

\section{Material and methods}

\subsection{FAHM experimental site}

The study was performed in the FAHM experimental site in hemiboreal Estonia $\left(58^{\circ} 19^{\prime} 40^{\prime \prime} \mathrm{N}, 26^{\circ} 33^{\prime} 16^{\prime \prime} \mathrm{E}\right)$, with data collected from six circular $(\varnothing 14 \mathrm{~m})$ experimental plots: three control plots $(C)$ with ambient conditions and three plots with artificially elevated air humidity (H). A computer-controlled system of mist emitters $(\sim 10-\mu \mathrm{m}$ water droplets are emitted using button-type misting nozzles; Mist Cooling Inc., Richmond, TX) and air-blowers surrounded the humidification plots and enabled to elevate relative air humidity inside the plots by $7 \%$ as a long-term seasonal average (Sellin et al., 2017a). The plots were distributed across the 2.7-ha FAHM site, which lies on former agricultural land (soil type: Endogleyic Planosol). A detailed technical description of the FAHM facility is provided in Kupper et al. (2011) and Tullus et al (2012b).

Hybrid aspen (Populus tremula L. $\times$ P. tremuloides Michx.) stands covered one half (ca $54 \mathrm{~m}^{2}$ ) of each experimental plot. One-year-old hybrid aspens (clone C05-99-34) were planted in autumn 2006 with a spacing of $1 \times 1 \mathrm{~m}$. A hybrid aspen plantation was also established as a buffer zone surrounding the plots. The six experimental hybrid aspen stands were harvested (all the trees were cut near the ground level and removed from the site) in winter 2012/13. In spring 2013, a new stand generation initiated from root and stump sprouts. Air humidity manipulation started in 2008 and has been running constantly for 11 growing periods. During the study period, the ambient weather conditions fluctuated from dry to wet (Table 1 ).

\subsection{Tree growth measurements}

After the first post-harvest growing period (2013), the densities of vegetatively regenerated hybrid aspen root sprouts (per $\mathrm{m}^{2}$ ) and stump sprouts (per parent tree stump) were estimated. In the second postharvest year (2014), the experimental stands were thinned to one sprout per parent stump to guarantee the homogenisation of humidified air within plots and to facilitate the field work and measurements.

Above-ground growth characteristics of all hybrid aspens (initial $n=248)$ inside the experimental plots $(n=6)$ were measured over 6 years (2013-2018) of the second rotation period. Tree height $(H)$ was recorded to the nearest $\mathrm{cm}$ after all growing seasons, initially with a 3.5-meter extendable measuring rod and later with an 8-meter Nedo mEssfix-S telescopic measuring rod (Nedo GmbH \& Co. KG, Germany). Since the second post-harvest year (2014), stem diameter $(D)$ at $30 \mathrm{~cm}$ from ground level has been measured in two perpendicular directions using a digital calliper (resolution: $0.01 \mathrm{~mm}$; Mitutoyo, Japan).

Growth data of planted hybrid aspens, collected during the first

Table 1

Precipitation and average temperature during the growing periods (May-October) of the study years; percentage from the maximum value is given in parentheses (data from automatic weather station at the FAHM site).

\begin{tabular}{llll}
\hline Year & Precipitation $(\mathrm{mm})$ & Temperature $\left({ }^{\circ} \mathrm{C}\right)$ & Dry and wet months \\
\hline 2008 & $502(100 \%)$ & $13.1(86 \%)$ & dry: V, wet: VIII \\
2009 & $468(93 \%)$ & $14.7(97 \%)$ & dry: V, wet: VI \\
2010 & $387(77 \%)$ & $14.9(98 \%)$ & dry: VII, wet: IX \\
2011 & $261(52 \%)$ & $15.2(100 \%)$ & dry: VI, VII \\
2012 & $339(67 \%)$ & $13.2(87 \%)$ & dry: VII \\
2013 & $302(60 \%)$ & $14.2(93 \%)$ & - \\
2014 & $385(77 \%)$ & $13.2(87 \%)$ & - \\
2015 & $228(45 \%)$ & $12.8(84 \%)$ & dry: VIII \\
2016 & $347(69 \%)$ & $13.7(90 \%)$ & dry: V, wet: VI \\
2017 & $379(75 \%)$ & $12.2(80 \%)$ & wet: VIII, IX \\
2018 & $318(63 \%)$ & $15.0(99 \%)$ & dry: V, VII \\
\hline
\end{tabular}

a The month was considered dry when precipitation $<2 \times$ temperature and wet, when precipitation $>100 \mathrm{~mm}$. 
rotation period (2007-2012) by the same working group, were used for compiling the long-term growth curves and for determining differences in tree- and stand-level responses to air humidification between the two generations. For the first time, the effect of humidification on current annual increment of hybrid aspen during the first rotation period was evaluated with repeated-measures analysis, while mean growth responses have been tested on a yearly basis in our previous papers (Tullus et al., 2012b, 2017; Niglas et al., 2014; Rosenvald et al., 2014; Sellin et al., 2017a). The growth dynamics of trees during the second rotation or comparatively across the two rotations has not been analysed before.

\subsection{Data analysis}

We analysed the effect of elevated air humidity on tree height and stem basal area (calculated from stem diameter at $30 \mathrm{~cm}$ height) at the end of both rotations (in 2012 and 2018, respectively) using linear mixed models (LMM), where treatment (control, i.e. ambient or elevated air humidity) was a fixed factor and plot was a random factor. The responses of current annual increment and relative growth rate (difference in logarithms of the growth characteristic between the current and previous year) were analysed with LMM for repeated measures, where humidification and year were fixed factors and plot and tree were random factors, to account for spatial and temporal dependencies in data. For better readability, in the graphs, we present relative growth rates without log-transformation. To analyse the effect of parent tree size on the growth of re-sprouting trees, stem diameter of parent tree at harvest was included as a covariate in the models. The effect of humidification on the number of living root sprouts, stump sprouts and total number of sprouts after the first post-harvest growing season was analysed with a Poisson generalised linear mixed model (GLMM). The significance of the humidification effect in GLMMs was evaluated by comparing each full model with the intercept-only model, using the $\chi^{2}$ test. Mixed model analyses were performed using the lmer (LMM) and glmer (GLMM) functions in the package lme4 in R Statistics (R Core Team, 2018). The significances of factors in LMMs were calculated with Satterthwaite's method (package lmerTest). The groups were compared according to estimated marginal means with the emmeans function and covariate slopes were contrasted with the emtrends function (package emmeans).

The effect of humidification on survival of the stump sprouts during the 6-year study period was analysed with a mixed effect Cox model, where the plot was a random factor. The model was fitted using the coxme function (package coxme) in R.

To clarify the size asymmetry in growth, size-growth relationships (SGR) were estimated for all plots and study years as linear regression slopes between current year proportional volume increment and proportional volume in previous year (Metsaranta and Lieffers, 2010). Proportional volume and increment of each tree were estimated based on stem volume index $\left(D^{2} H\right)$ separately for each experimental stand (plot), and the centered log-ratio transformation was applied to meet the statistical assumptions (Aitchison, 1986). The SGR can be sizeasymmetric ( $\mathrm{SGR}>1$ ), size-symmetric ( $\mathrm{SGR}=1$ ) or inverse size asymmetric (SGR < 1) (Metsaranta and Lieffers 2010). To test the treatment effect on the SGR slope an LMM with random slopes was used. More precisely, the model constrained the SGR slope to pass through the origin and allowed the slope to vary for each plot.

Stand structural diversity of each plot and study year was characterised with Tree Height Diversity (THD, e.g. Kuuluvainen et al., 1996; Staudhammer and LeMay, 2001), which was calculated using the Shannon-Weaver formula (Eq. (1)):

$T H D=H^{\prime}=-\sum_{i=1}^{n} p_{i} \log \left(p_{i}\right)$

where $p_{i}$ is the proportion (based on basal area) of trees in the ith 1-m vertical height layer in the given plot.

As structural diversity development was more precisely determined by the size of trees in the given stand (experimental plot) than by age (year), the effects of humidification and rotation period on THD (pooled data from all plots and years) were evaluated with LMMs, where mean height or stand basal area were added as a covariate. Skewness of stem diameter distribution $\left(\mathrm{SKEW}_{D}\right)$ as another measure of structural diversity and competition intensity was also estimated (e.g. Kenkel et al., 1997; Xue and Hagihara, 1999; Coomes and Allen 2007). The relationships between the annual change in THD ( $\triangle$ THD) and the skewness of $D\left(\triangle \mathrm{SKEW}_{D}\right)$ and environmental variables (precipitation and temperature) were analysed with linear regression separately for $\mathbf{C}$ and $\mathbf{H}$ plots (because there were too few observations to test for the $\mathbf{C}$ vs. $\mathbf{H}$ difference).

The model assumptions were checked visually from residuals histograms and Q-Q plots; when necessary, log-transformation was applied. The significance level $\alpha=0.05$ was used to determine the statistical significance of the effects. As we applied rather conservative statistical methods, then $p$-values $<0.1$ are also highlighted as marginally significant.

\section{Results}

\subsection{Initial density and survival of re-sprouting hybrid aspens}

By the end of the first post-harvest season, on average, $6.6 \pm 0.38$ sprouts $\mathrm{m}^{-2}$ had emerged in $\mathbf{H}$ plots, which was by $19 \%$ less $(p=0.009)$ than in $\mathrm{C}$ plots $\left(8.1 \pm 0.41\right.$ sprouts $\left.\mathrm{m}^{-2}\right)$. A significant difference was observed in the number of root sprouts $(p=0.016)$, but the average number of stump sprouts per stump did not differ between the treatments ( $p=0.935$; Fig. 1A). After thinning the experimental stands to one sprout per stump in the second year (2013), the further mortality of trees remained significantly (Cox model, $p=0.035$ ) lower in $\mathbf{H}$ plots, where the average survival was $78 \pm 6.4 \%$ by the end of year six compared to $58 \pm 6.8 \%$ in the $\mathrm{C}$ plots (Fig. 1B).

\subsection{Growth dynamics}

Comparison of above-ground growth dynamics of planted hybrid aspens during the first rotation period revealed significant $(p<0.001)$ year-dependent differences in current annual increment in stem height and individual tree basal area between $\mathbf{H}$ and $\mathbf{C}$ stands (Figs. 2 and 3). A strong negative growth response to air humidification was observed in some years, but no response or a small growth enhancement occurred in other years. The dominating negative effect resulted in a $23 \%$ smaller $(p=0.035)$ mean basal area in $\mathbf{H}$ plots at the end of the first rotation (Fig. 3A). The final mean height tended to be $7 \%$ smaller in $\mathbf{H}$ compared to $\mathrm{C}$ plots, but this difference was not significant ( $p=0.369$; Fig. $2 \mathrm{~A}$ ).

In re-sprouting hybrid aspen stands (the second rotation period), total height (Fig. 2A) and basal area (Fig. 3A) did not differ between the treatments at the end of the 6-year period. However, there were still some significant $(p<0.001)$ year-dependent differences in annual increments between $\mathbf{C}$ and $\mathbf{H}$ plots (Fig. $2 \mathrm{~B}, \mathrm{C}$ and $3 \mathrm{~B}, \mathrm{C}$ ). The negative growth response to humidification was detected only in the relative height increment of the second year, but in other years, no effect or a positive effect (in years four and six) of air humidification occurred. Compared to the planted trees of the first study period, the growth dynamics during the second rotation was characterised by faster initial growth acceleration, followed by growth reduction after thinning and growth recovery in the final year. The post-thinning growth reduction was somewhat smaller and recovery was faster in $\mathbf{H}$ plots (Fig. 2C). Across the two rotation periods, the means of annual height and basal area increment displayed greater ranges in C plots, where both maximum as well as minimum increment means were observed. 

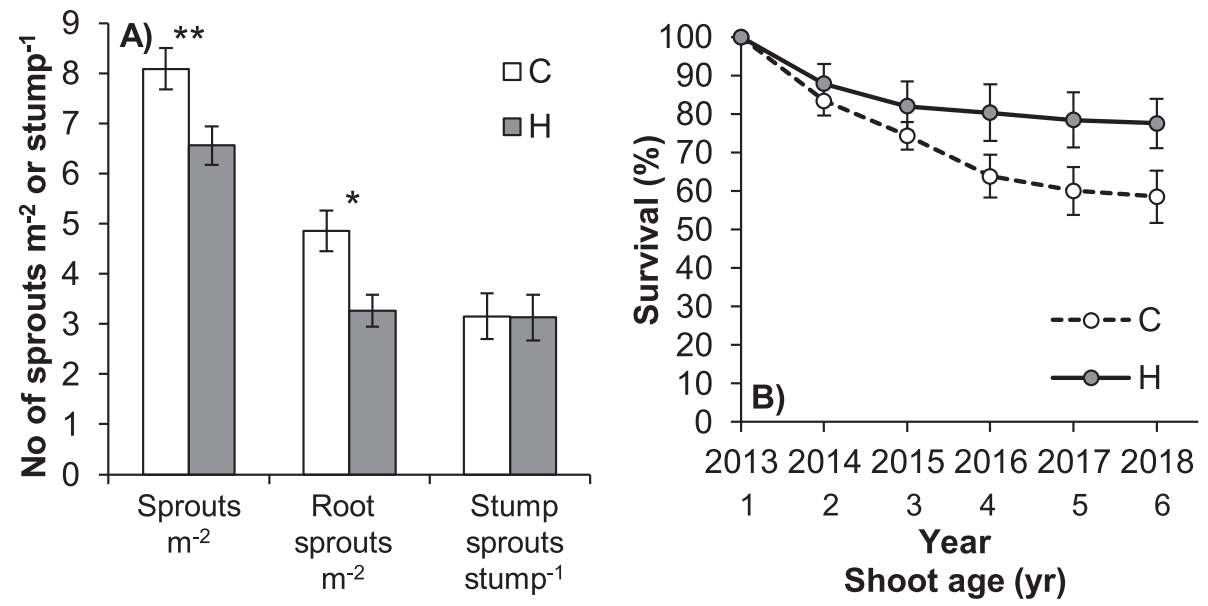

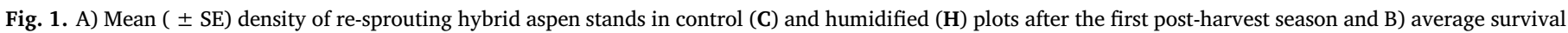
of trees during the 6-year period. Treatment effect (GLMM): ${ }^{*} p<0.05$, ${ }^{* *} p<0.01$.

\subsection{Size-growth relations and structural diversity}

The growth of re-sprouting hybrid aspens was significantly affected by the size of the parent tree ( $\left.D_{\text {PARENT }}\right)$, and this effect was year-specific (Fig. 4A, B). Basal area increment was generally more strongly affected by $D_{\text {PARENT }}$ than height increment. In some years, significant differences in the respective slopes existed between $\mathbf{H}$ and $\mathbf{C}$ plots. Interestingly, in humidified plots, the effect of $D_{\text {PARENT }}$ on basal area increment tended to increase with age and was greater than in control plots across all years (pairwise $t$-test, $p=0.045$ ).

Additionally, we analysed the size-growth relationships (SGR) across the two rotation periods (Fig. 4C). In C plots, SGR was significantly greater than 1 in 3 years, and the average SGR was $1.12 \pm 0.05$, indicating size-asymmetric growth (SGR vs. 1 , singlesample $t$-test, $p=0.054$ ). In $\mathbf{H}$ plots, SGR differed from 1 only in 1 year, and the average SGR was $1.00 \pm 0.04$, indicating completely sizesymmetric growth. In three out of eight observation years, SGR differed significantly between $\mathbf{C}$ and $\mathbf{H}$ plots.

Stand structural diversity, characterised by Tree Height Diversity (THD), increased with tree age and mean size (Fig. 5). The increase in THD was more persistent in $\mathbf{H}$ plots, while it fluctuated more in $\mathbf{C}$ plots (Fig. 5A). However, by the end of both rotations, it achieved comparable levels in $\mathbf{C}$ and $\mathbf{H}$. In the second rotation period, the structural diversity of re-sprouting hybrid aspen stands continued to develop from the approximately same level which it had reached by the end of the first rotation period (Fig. 5A). The THD did not depend on treatment in the first rotation period, but was significantly greater in $\mathbf{H}$ plots during the second rotation period (LMM with plot mean height as covariate: 'rotation $\times$ treatment', $p=0.031$ ). The rise in THD with increasing mean size of trees was significantly steeper in the second rotation period ('rotation $\times$ height': $p<0.001$, 'rotation $\times$ stand basal area', $p=0.014$ ), when trees at the fastest-growing plots reached almost twofold greater THD values than plots with similar tree size in the first rotation period (Fig. 5B, C). The slope between THD and mean size of trees increased more in $\mathbf{C}$ compared to $\mathbf{H}$ plots between the two rotations ('rotation $\times$ height $\times$ treatment', $p=0.036$ ).

During the first rotation period, the initially positive skewness of diameter distribution declined with age similarly both in $\mathbf{C}$ and $\mathbf{H}$ plots (Fig. 6A). During the second rotation period, skewness decreased further in humidified plots until becoming slightly negative in the final year but remained relatively stable in control plots, where it peaked in 2016. In both $\mathbf{H}$ and $\mathbf{C}$ plots the annual change in THD ( $\Delta$ THD) was positively correlated with precipitation during the growing period, whereas the regression slope tended to be steeper in C plots (Fig. 6B, C). In the two years with the lowest precipitation rate $(<300 \mathrm{~mm}), \Delta \mathrm{THD}$ was close to zero in $\mathbf{H}$ plots and negative in $\mathbf{C}$ plots. The annual change in skewness of diameter distribution was also in positive correlation with precipitation during the growing period in $\mathbf{H}$ plots but not in $\mathbf{C}$ plots. Mean temperature during the growing period had no effect on the mentioned variables. However, it must be noted that for calculating the annual changes in $\mathrm{SKEW}_{D}$ and THD, values from two consecutive years were required, and we only had eight yearly observations in total available from both $\mathbf{C}$ and $\mathbf{H}$ plots, which limited the descriptive power of the regression analysis.

\section{Discussion}

\subsection{Evidence of hybrid aspen growth acclimation to elevated air humidity}

Smaller annual growth increment of hybrid aspen trees was repeatedly observed in response to elevated air humidity during the first 6 -year rotation, but signs of growth recovery appeared in the resprouting (second rotation) stands, contrarily to our hypothesis. Probably, root-level acclimation had gradually taken place, which was maintained after harvest and passed on to the new tree generation that initiated from root and stump sprouts. Elevated humidity reduces transpiration (Kupper et al., 2011) and nutrient supply to foliage (Tullus et al., 2012b) and maintains a high soil water content (Hansen et al., 2013), creating temporarily hypoxic conditions that impair nutrient uptake, hydraulic efficiency, photosynthetic capacity and foliar metabolism (Sellin et al., 2017a, 2017b; Oksanen et al., 2019). In response, the specific fine-root surface area and the phosphorus content were significantly higher and average fine-root biomass tended to be greater in humidified aspens at the end of the first rotation period (Rosenvald et al., 2014). In addition to changes in biomass allocation and anatomical acclimation to higher air humidity, root-colonising EcM fungal communities are changed under humidification (Parts et al., 2013). In agreement with our findings, Orság et al. (2018) recently showed that once the root system is established, hybrid poplar plantations are relatively resilient to climate fluctuations (reduced rainfall). At the same time, in a two-rotation coppice system with different poplar species, the growth-stimulating effect of elevated $\mathrm{CO}_{2}$ levels persisted during both rotations (Liberloo et al., 2006). Unlike elevated $\mathrm{CO}_{2}$, the previously observed changes in tree physiology and functioning in the FAHM experiment suggest that increased environmental humidity due to reduced atmospheric evaporative demand induces stress reaction in trees growing in hemiboreal zone (Sellin et al., 2017a). Under stress (especially mild stress) conditions, partial or full recovery of tree functioning usually occurs (Niinemets, 2010) and the current study revealed that the growth rate of hybrid aspen was able to recover completely after long-term exposure to elevated air humidity. Moreover, we demonstrated that elevated air humidity mitigated drought 


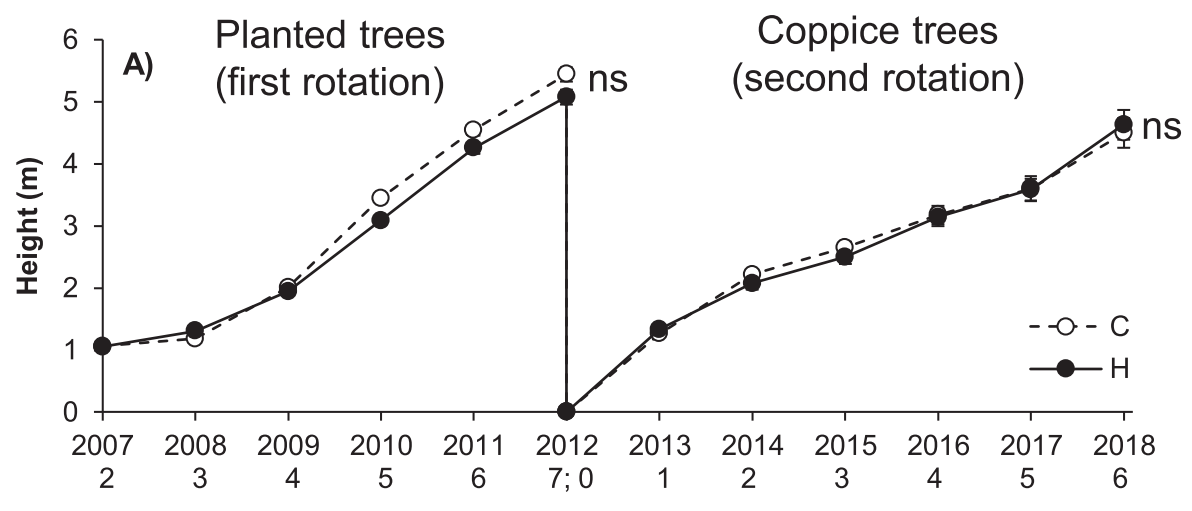

Year / Shoot age (yr)

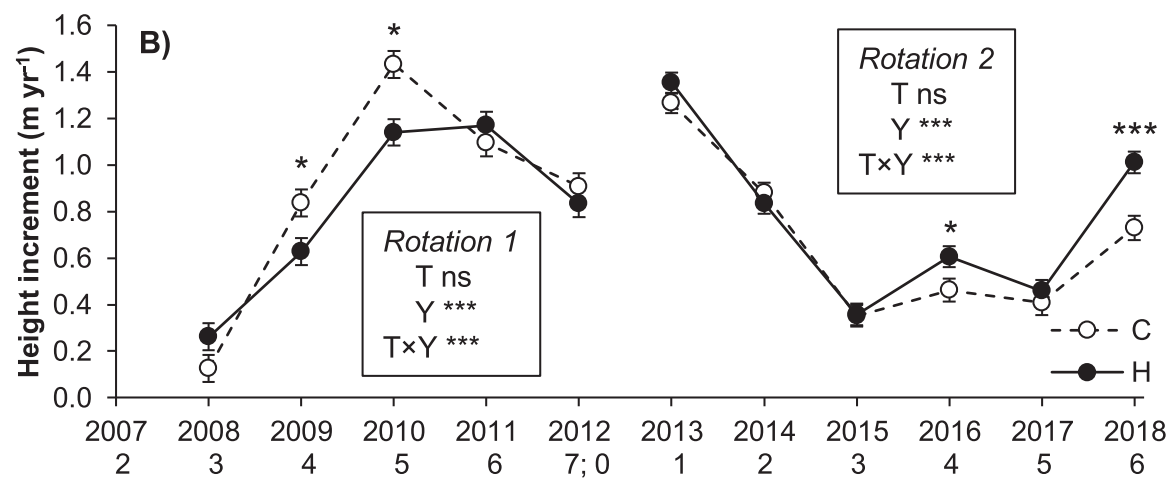

Year / Shoot age (yr)

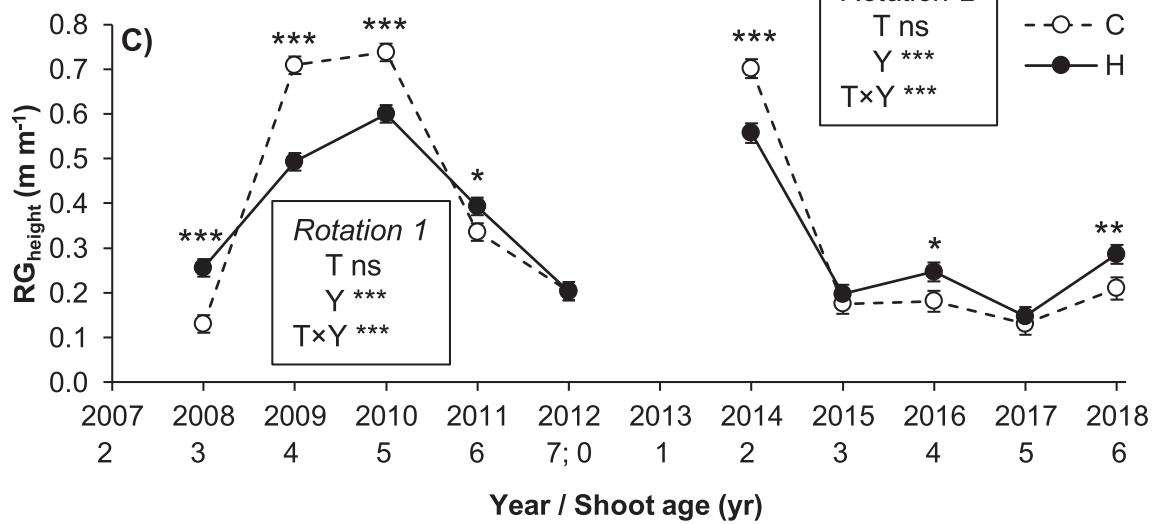

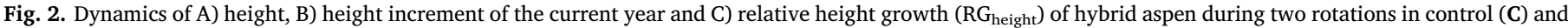

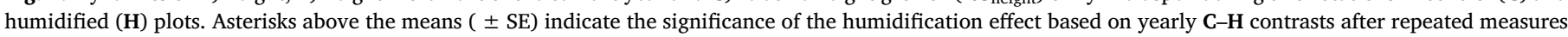

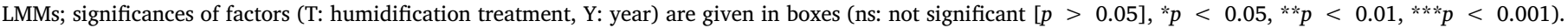

stress, resulting in lower mortality and less drastic growth reduction in humidified trees in dry seasons. Similarly, the responsiveness of $P$. tremula to both increased temperature and UV-B radiation gradually weakened with tree age (Strømme et al., 2019).

The initial density of root sprouts was smaller in humidified stands. Parent trees had smaller above-ground dimensions at the time of harvest, and therefore, their root systems were probably also smaller. Besides that, higher soil moisture in humidified stands (Kukumägi et al., 2014) can lower the sprouting capacity of aspen roots (Frey et al., 2003).

We did not observe an overall faster growth of trees during the second rotation compared to the first rotation with planted trees, as often reported in re-sprouting aspen and poplar coppicing systems (Pontailler et al., 1999, Verlinden et al., 2015, Vanbeveren and Ceulemans, 2018), except in the first year after harvest. This could have resulted from additional stress caused by heavy thinning of stands from seven or eight sprouts to one sprout per stump, inducing the trees to invest more resources to maintain the parental root system relative to the above-ground growth because of the imbalance created between leaf area and root system size (DesRochers and Lieffers, 2001). However, thinning was inevitable to keep the FAHM experiment running and to enable various measurements at different levels of organization. Moreover, thinning of hybrid aspen coppice stands already at the age of 2 (Rytter, 2006) or 4 years (Rytter and Rytter, 2017) is proposed as a potential management strategy.

\subsection{Confounding effect of growing season precipitation}

In both rotations, the growth response to humidification was positive in years with drought during the onset of the growing period (May 


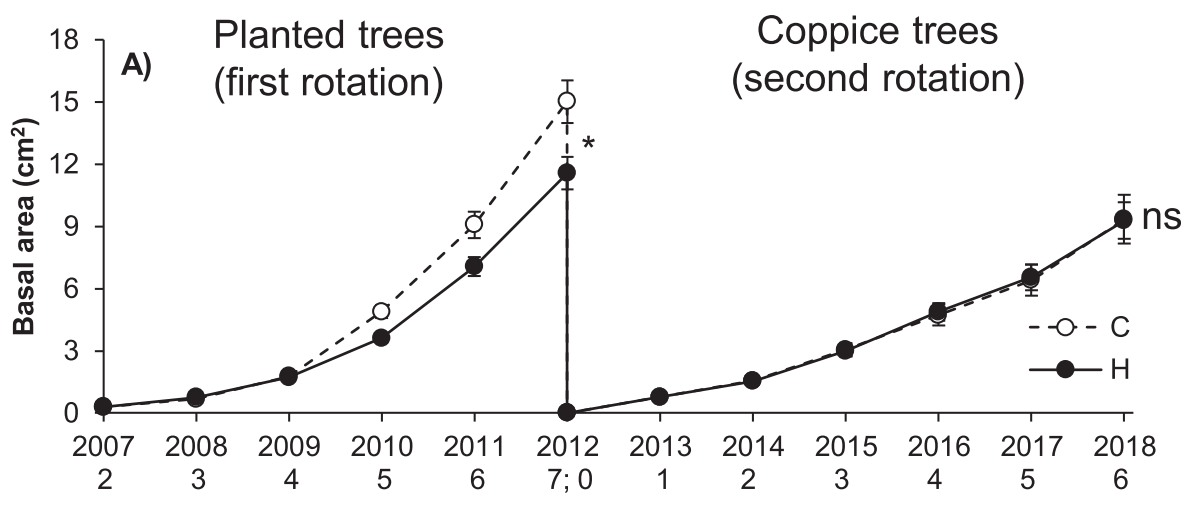

Year / Shoot age (yr)
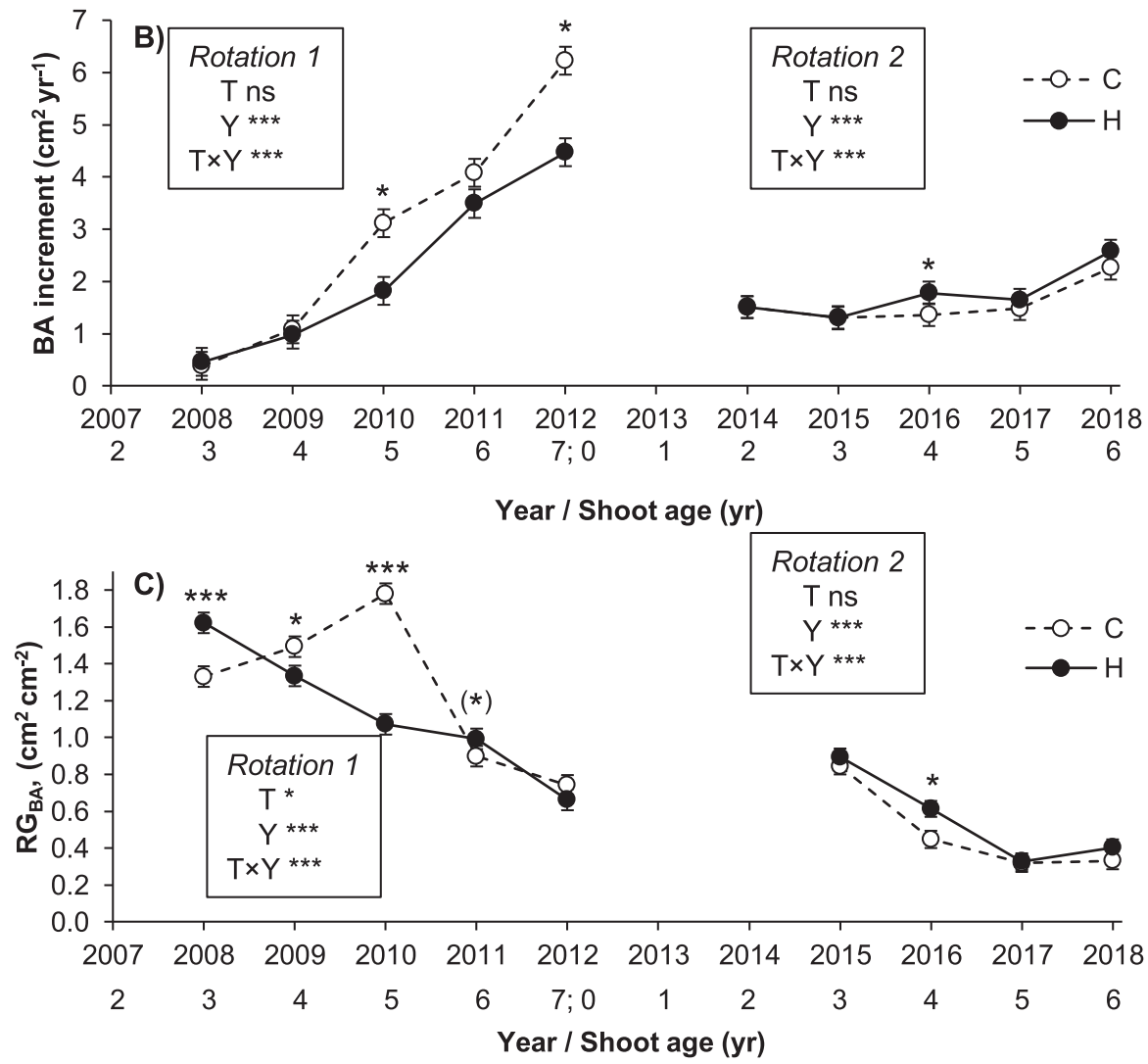

Fig. 3. Dynamics of A) stem basal area at $30 \mathrm{~cm}$ height, B) basal area increment of the current year and C) relative basal area growth (RG $\mathrm{BA}_{\mathrm{B}}$ ) of hybrid aspen during two rotations in control $(\mathbf{C})$ and humidified $(\mathbf{H})$ plots. Asterisks above means $( \pm \mathrm{SE}$ ) indicate the significance of the humidification effect based on yearly $\mathbf{C}-\mathbf{H}$ contrasts after repeated measures LMMs; significances of factors (T: humidification treatment, Y: year) are given in boxes (ns: not significant $[p>0.1]$, ${ }^{(*)} p<0.1$, $\left.{ }^{*} p<0.05, * * p<0.01,{ }^{* * *} p<0.001\right)$.

or June), followed by normal or slightly wet summers (e.g. 2008, 2011, 2016 and 2018). As an exception, the dry May in 2009 was followed by an overly rainy summer, resulting in decreased increments. The growth response was negative or non-significant in years with high or normal precipitation during the first half of the growing period $(2010,2012$, 2013-2015, 2017). Such years better mimic the future wetter conditions predicted for the region (Kont et al., 2003; Oksanen et al., 2019). The fluctuations of mean annual growth increment showed that under mild to moderate stress caused by humidification, trees responded with smaller growth reduction to non-optimal (other) weather conditions. Nevertheless, they were not able to achieve the maximal potential growth rate. Therefore, the possible negative impact from the increasing frequency of drought on trees and forests in northern temperate and southern boreal regions (Spinoni et al., 2017) might be somewhat reduced by moister weather conditions.

\subsection{Carry-over of size hierarchy in coppice stands of hybrid aspen}

We detected a significant positive effect of the parent trees stump size ( $\left.D_{\text {PARENT }}\right)$ on re-sprouting shoot growth. In poplars (Populus spp.), managed in two 3-year rotations, no significant relation between $D_{\text {PARENT }}$ and second-cycle biomass production was observed, although a positive trend existed (Liberloo et al., 2006). In our study, the cycles were longer (6 years), and the coppice stands were thinned to one sprout per stump. As stem diameter is strongly correlated with size and extension of the root system (Rosenvald et al., 2014), the observed carry-over of size hierarchy (reflecting also trees competitive status) implies the significance of root extension for below-ground resource acquisition in more stressful conditions of wet soil. The relation with $D_{\text {PARENT }}$ strengthened with age in humidified stands, and hence, small differences in microsite characteristics played a more important long- 

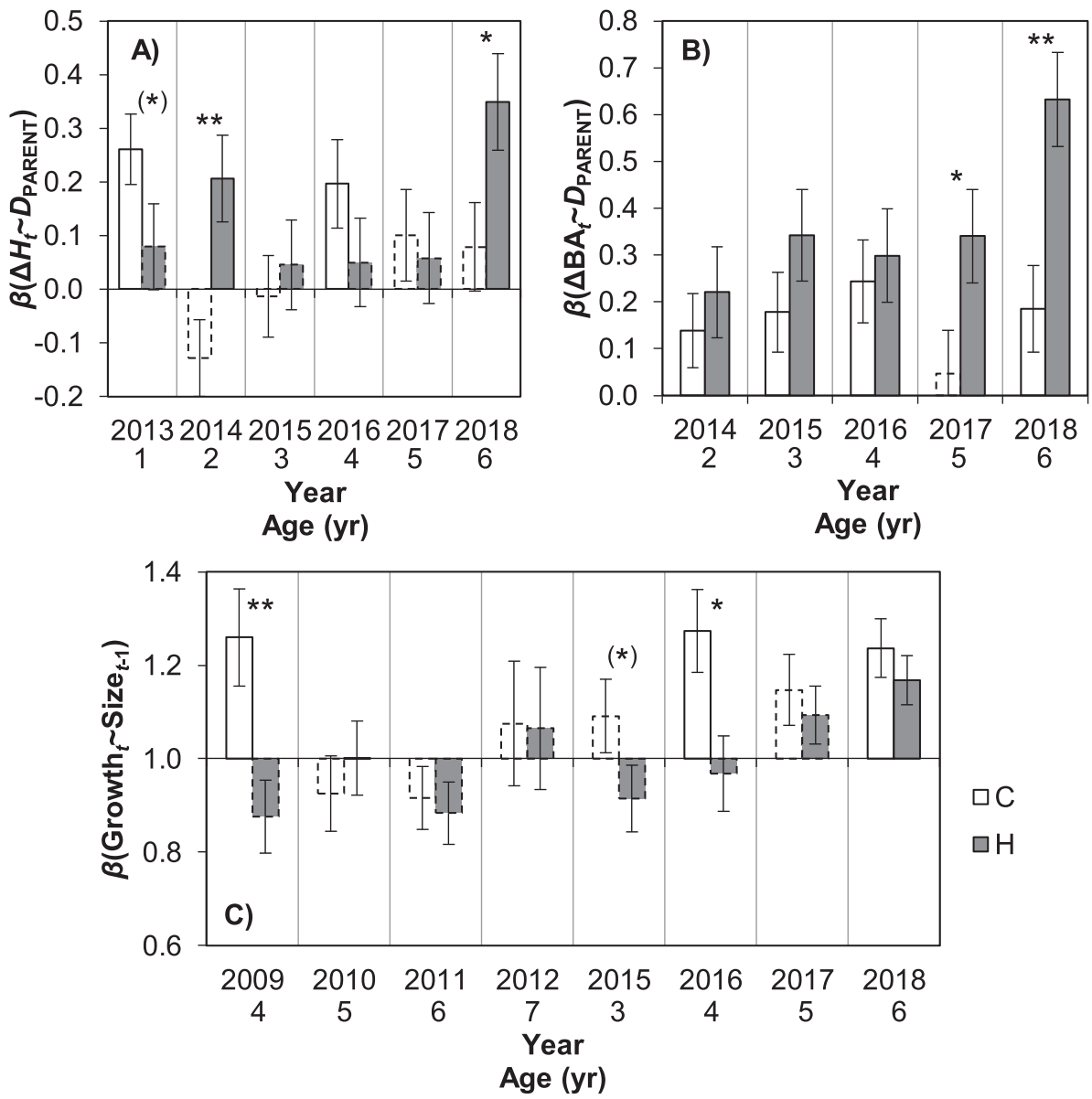

Fig. 4. Standardised slopes (coefficients \pm SE from LMMs) in control (C) and humidified (H) plots between A) current annual increment of height $\left(\Delta H_{t}\right)$ and stem diameter of parent tree $\left(D_{\text {PARENT }}\right)$, B) current annual increment of stem basal area $\left(\Delta \mathrm{BA}_{t}\right)$ and stem diameter of parent tree and $\mathrm{C}$ ) deviance from 1:1 line in size-growth relationship (SGR). Slopes that did not differ significantly from 0 (A, B) or 1 (C) are indicated by a dashed line, the significances of annual $\mathbf{C}-\mathbf{H}$ differences are indicated with asterisks: ${ }^{(*)} p<0.1, * p<0.05, * * p<0.01$. term role in determining tree growth than possible above-ground interactions. In humidified FAHM stands, nutrient acquisition by trees is hindered due to reduced transpiration-driven mass flow of mobile nutrients as well as more frequent hypoxic soil conditions (Tullus et al., 2012b; Sellin et al., 2017a). Therefore, the occupation of nutrient-rich (or less water-saturated) soil patches might be more crucial in elevated than in ambient humidity conditions, where the nutrient demand of trees was apparently well met at the FAHM site on former fertile agricultural land.

\subsection{Stand size structure and intensity of root and shoot competition}

The SGR was usually symmetric in humidified stands, meaning that trees were growing proportionally to their size, which could point to more intensive root competition (Casper and Jackson, 1997; Cahill and Casper, 2000; von Wettberg and Weiner, 2003) under elevated humidity conditions. Root competition not only with other trees, but also with understory vegetation was probably more intense because of the significantly higher root biomass of understory vegetation in humidified plots (Lõhmus et al., 2019). Also, our previous analysis of the interactive effect of humidification and competitive status on the growth of planted hybrid aspens during the first rotation period showed that the increments of competitively advantaged aspens were more strictly proportional to tree size in humidified than in control stands, where advantaged trees displayed an asymmetrically faster growth (Tullus et al., 2017). Asymmetric SGR in control stands, meaning that larger trees grew disproportionally faster than smaller trees, suggests the predominance of light competition, which could be one reason behind the greater mortality in the second re-sprouting generation, as often observed in young stands where self-thinning has started (Xue and Hagihara, 1999; Coomes and Allen, 2007). Asymmetric competition usually prevails when nutrient availability is not restricted (Wichmann, 2001).

The skewness of tree size distribution is expected to increase until the self-thinning point is reached at canopy closure (Weiner and Thomas, 1986; Kenkel et al., 1997). From this point onwards, size distribution of trees in a stand becomes less skewed as a result of intensifying asymmetric competition, usually interpreted as competition for light (Xue and Hagihara, 1999; Coomes and Allen, 2007). This is in accordance with that we observed during the first rotation period in planted trees, where skewness began to decline during the last years in both treatments. However, in the second rotation with re-sprouting aspens, the trajectories of stem diameter skewness dynamics departed considerably between $\mathbf{C}$ and $\mathbf{H}$ plots. As the shoot dimensions of trees were still relatively small, the intensity of light competition was accordingly low during the first years of the second rotation. Therefore, below-ground interactions were probably responsible for the observed changes in above-ground size distribution in humidified coppice stands. In aspen coppice stands, the parent tree's root system remains alive after above-ground harvest (Bärring, 1988 and citations therein) and is therefore older than the re-sprouting shoots. The nutrient acquisition capacity and the root health condition may therefore become increasingly decisive in such systems. Thus, the observed pattern in $\mathrm{SKEW}_{D}$ in humidified plots can be explained by the elements of asymmetry also in belowground interactions (Schwinning and Weiner, 1998).

The THD mostly increased with tree age, more eminently in normal and rainy years, but decreased in dry years (2011 and 2015) in control stands, whereas mortality in control stands was also high in the year with the lowest precipitation during the growing period (2015) and in the following year 2016. It is often observed that tree mortality increases with a certain lag after drought (Vanoni et al., 2016). In terms of lower mortality, elevated air humidity clearly mitigated drought 

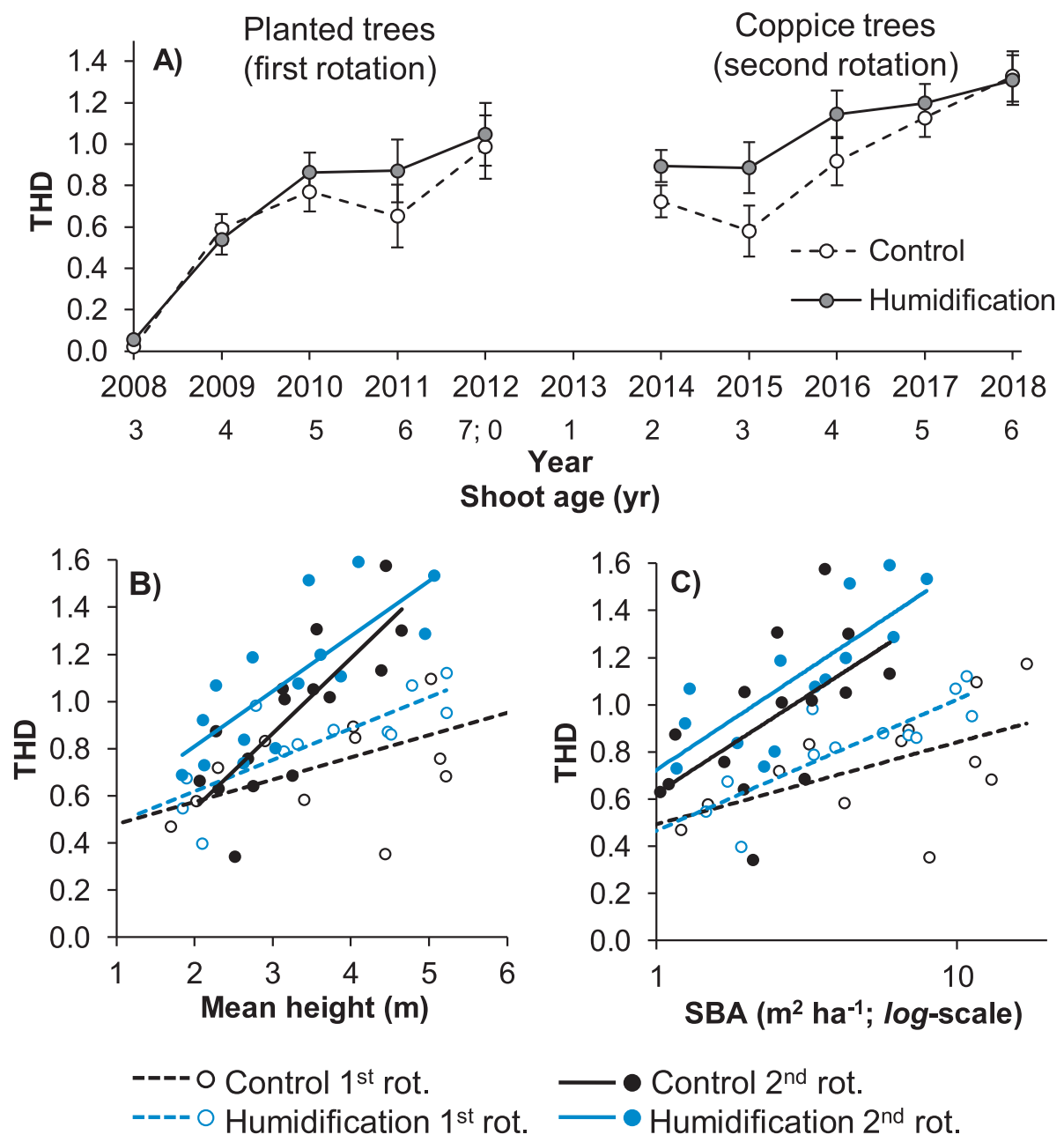

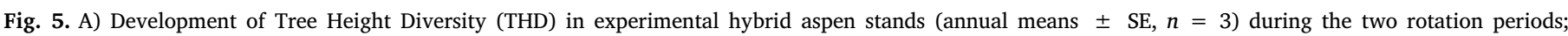

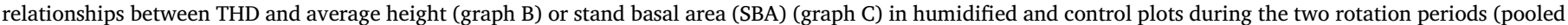
data from all years and plots).

stress in hybrid aspen. The reduction of THD in control stands in dry years accords with the observations that larger trees are more severely stressed by drought (Wichmann, 2001; Pretzsch and Dieler, 2011) and were less intensively occupying new height classes; meanwhile, less affected smaller trees probably "escaped" from lower height classes. In humidified plots, THD remained unchanged in dry years, but SKEW declined at most in these years. As the depletion of soil moisture reserves in dry years was slower in humidified plots (Sellin et al., 2017a), apparently, the trees were able to allocate more to above-ground growth and were therefore more affected by (asymmetric) light competition. The THD increased with mean size significantly faster in the second-generation stands, indicating the more substantial role of belowground interactions in growth differentiation in the coppice generation. The THD of the humidified second-generation stands was significantly higher than that in control stands with the same average height. This finding suggests that aspen coppice forests become more diversely structured than planted stands, whereas elevated humidity seems to favour a higher THD. This happens probably partly because of the lower mortality, i.e. the higher share of trees in small size-classes.

\section{Conclusions}

Short- and long-term responses of hybrid aspen to elevated air humidity differed with indications of complete growth acclimation during the re-sprouting stand generation. Therefore, in coppicing trees, conclusions about climate change effects from one rotation period may not be entirely valid in the long term across several rotations. The observed patterns of stand structure dynamics (more symmetric size-growth relationship, faster decline in skewness of size distribution) suggest that below-ground interactions play a greater role under elevated air humidity conditions. The early development of tree height diversity was enhanced under elevated humidity, apparently because of the reduced drought effects (lower drought-induced mortality and less retarded growth). Changes in air humidity and consequent changes in soil moisture have significant effects on aspen stand growth dynamics and structural development, which are carried over also to the post-harvest re-sprouting trees. Therefore, the role of root-level processes, including acclimation to higher soil moisture, and below-ground interactions in the development of stand structure in hemiboreal (northern temperate) conditions are likely not less important than shoot competition. Based on above-ground growth dynamics and survival of trees, hybrid aspen short-rotation coppice stands showed promising acclimation capacity to future more humid climate predicted for northern latitudes.

\section{Author Contributions Statement}

AT, AS and PK conceived the ideas and designed methodology; AT, RL and KR collected the data; AT and AK analysed the data; AT led the writing of the manuscript. All authors contributed critically to the drafts and gave final approval for publication. 


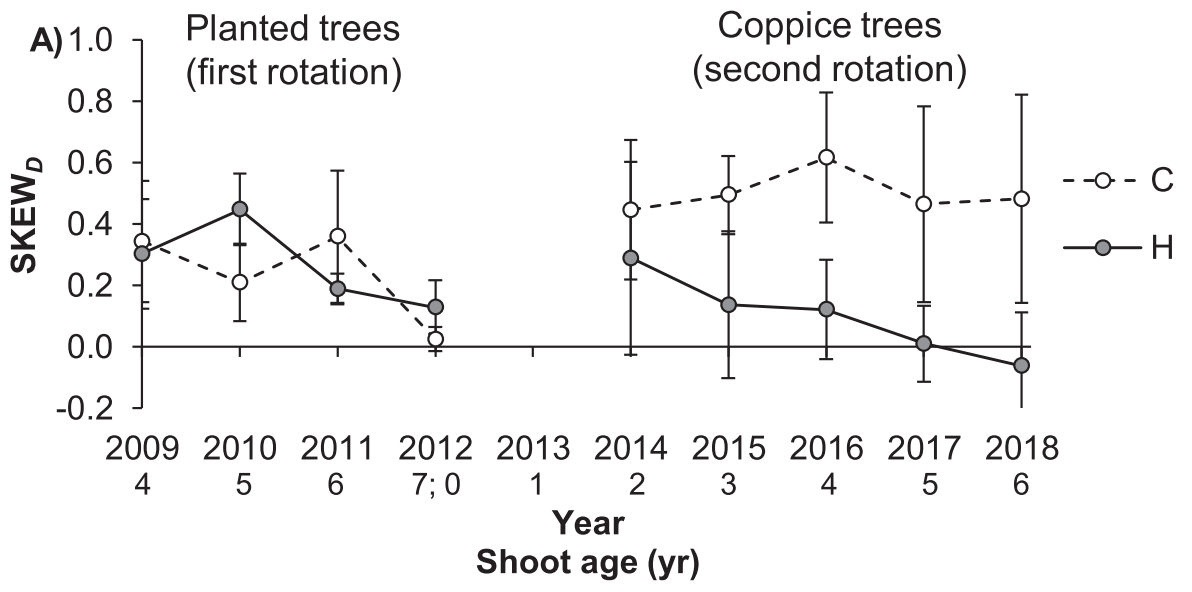

Fig. 6. A) Trajectory of the skewness of stem diameter distribution $\left(\mathrm{SKEW}_{D}\right)$ in humidified $(\mathbf{H})$ and control (C) stands (annual means \pm SE, $n=3$ ) during the two rotation periods, B) standardised linear regression slopes $(\beta \pm \mathrm{SE})$ between annual changes in $\operatorname{SKEW}_{D}\left(\triangle \mathrm{SKEW}_{D}\right)$ and precipitation during the growing period, i.e. from May to October $\left(\right.$ PREC $\left.\left._{\mathrm{V}-\mathrm{x}}\right), \mathrm{C}\right)$ relationships between annual change in Tree Height Diversity $(\triangle \mathrm{THD})$ and $\mathrm{PREC}_{\mathrm{V}-\mathrm{X}}$. Significances are indicated as follows: ns: $p>0.1$, $* * p<0.001$.
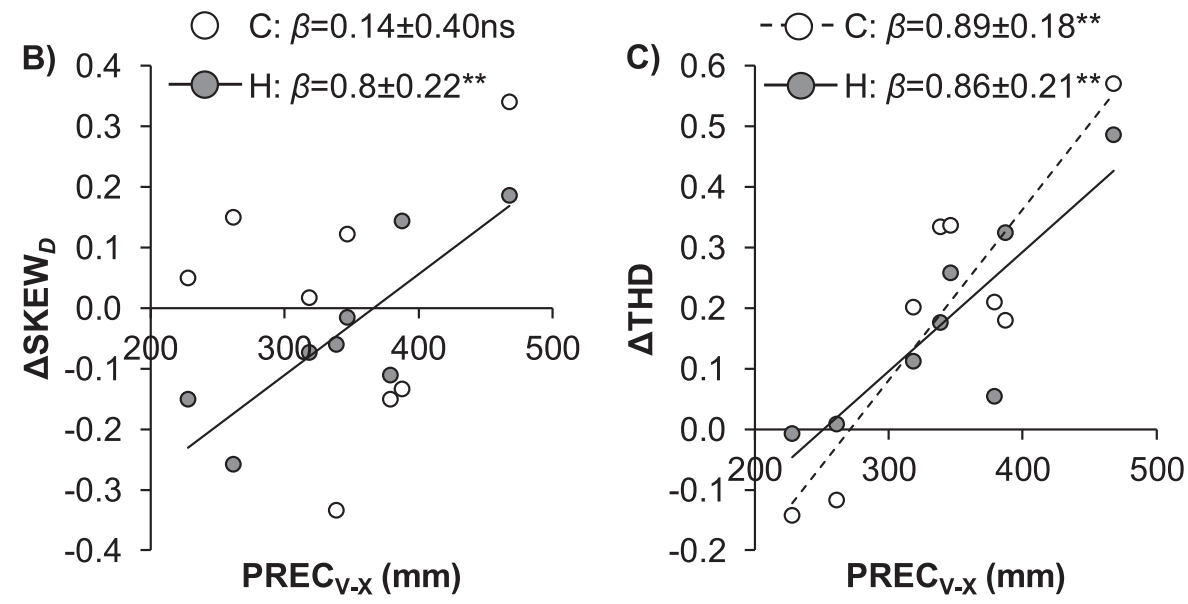

\section{Declaration of Competing Interest}

The authors declare that they have no known competing financial interests or personal relationships that could have appeared to influence the work reported in this paper.

\section{Acknowledgements}

This work was supported by the Estonian Research Council (grant PSG7) and by Institutional Research Funding (grants IUT21-4 and IUT34-9) from the Estonian Ministry of Education and Research. The authors would like to thank Mr. Jaak Sõber for operating the FAHM humidification system.

\section{References}

Aitchison, J., 1986. The statistical analysis of compositional data. Chapman, Hall, Ltd., London, UK.

Aussenac, G., 2000. Interactions between forest stands and microclimate: ecophysiological aspects and consequences for silviculture. Ann. For. Sci. 57, 287-301. https:// doi.org/10.1051/forest:2000119.

Barbeito, I., Cañellas, I., Montes, F., 2009. Evaluating the behaviour of vertical structure indices in Scots pine forests. Ann. For. Sci. 66 (7), 710p1-710p10. https://doi.org/10. 1051 /forest/2009056.

Bärring, U., 1988. On the reproduction of aspen (Populus tremula L.) with emphasis on its suckering ability. Scand. J. For. Res. 3 (1-4), 229-240. https://doi.org/10.1080/ 02827588809382511.

Cahill, J.F., Casper, B.B., 2000. Investigating the relationship between neighbor root biomass and belowground competition: field evidence for symmetric competition belowground. Oikos 90, 311-320. https://doi.org/10.1034/j.1600-0706.2000. 900211.x.

Calfapietra, C., Gielen, B., Sabatti, M., De Angelis, P., Miglietta, F., Scarascia-Mugnozza, G., Ceulemans, R., 2003. Do above-ground growth dynamics of poplar change with time under $\mathrm{CO}_{2}$ enrichment? New Phytol. 160, 305-318. https://doi.org/10.1046/j. 1469-8137.2003.00899.x.
Casper, B.B., Jackson, R.B., 1997. Plant competition underground. Annu. Rev. Ecol. Syst. 28, 545-570. https://doi.org/10.1146/annurev.ecolsys.28.1.545.

Coomes, D.A., Allen, R.B., 2007. Mortality and tree-size distributions in natural mixedage forests. J. Ecol. 95, 27-40. https://doi.org/10.1111/j.1365-2745.2006.01179.x.

Darbah, J.N.T., Jones, W.S., Burton, A.J., Nagy, J., Kubiske, M.E., 2011. Acute $\mathrm{O}_{3}$ damage on first year coppice sprouts of aspen and maple sprouts in an open-air experiment. J. Environ. Monit. 13, 2436-2442. https://doi.org/10.1039/c1em10269a.

David, A.J., Zasada, J.C., Gilmore, D.W., Ländhausser, S.M., 2001. Current trends in the management of aspen and mixed aspen forests for sustainable production. Forest Chron. 77 (3), 525-532. https://doi.org/10.5558/tfc77525-3.

Davies-Colley, R.J., Payne, G.W., van Elswijk, M., 2000. Microclimate gradients across a forest edge. N. Z. J. Ecol. 24 (2), 111-121.

DesRochers, A., Lieffers, V.J., 2001. The coarse-root system of mature Populus tremuloides in declining stands in Alberta, Canada. J. Veg. Sci. 12 (3), 355-360. https://doi.org/ $10.2307 / 3236849$.

Dickmann, D.I., Kuzovkina, J., 2014. Poplars and willows of the world, with emphasis on silviculturally important species. In: Isebrands, J.G., Richardson, J. (Eds.), Poplars and willows: trees for society and the environment. Published jointly by $\mathrm{CAB}$ International and FAO. pp. 8-91.

Edelfeldt, S., Lundkvist, A., Forkman, J., Verwijst, T., 2018. Effects of cutting traits and competition on performance and size hierarchy development over two cutting cycles in willow. Biomass Bioenerg. 108, 66-73. https://doi.org/10.1016/j.biombioe.2017. 11.002.

Frey, B.R., Lieffers, V.J., Landhäusser, S.M., Comeau, P.G., Greenway, K.J., 2003. An analysis of sucker regeneration of trembling aspen. Can. J. For. Res. 33, 1169-1179. https://doi.org/10.1139/X03-053.

Hansen, R., Mander, Ü., Soosaar, K., Maddison, M., Lõhmus, K., Kupper, P., Kanal, A., Sõber, J., 2013. Greenhouse gas fluxes in an open air humidity manipulation experiment. Landscape Ecol. 28 (4), 637-649. https://doi.org/10.1007/s10980-0129775-7.

Humphrey, J.W., Hawes, C., Peace, A.J., Ferris-Kaan, R., Jukes, M.R., 1999. Relationships between insect diversity and habitat characteristics in plantation forests. For. Ecol. Manage. 113 (1), 11-21. https://doi.org/10.1016/S0378-1127(98)00413-7.

Hytönen, J., 2018. Biomass, nutrient content and energy yield of short-rotation hybrid aspen (P. tremula x P. tremuloides) coppice. For. Ecol. Manage. 413, 21-31. https:// doi.org/10.1016/j.foreco.2018.01.056.

IPCC, 2014 Climate Change 2014: Synthesis Report. Contribution of Working Groups I, II and III to the Fifth Assessment Report of the Intergovernmental Panel on Climate Change (Eds. Core Writing Team, Pachauri RK, Meyer LA), pp. 12. IPCC, Geneva, Switzerland. 
Kenkel, N.C., Hendrie, M.L., Bella, I.E., 1997. A long-term study of Pinus banksiana population dynamics. J. Veg. Sci. 8, 241-254. https://doi.org/10.2307/3237353.

Kont, A., Jaagus, J., Aunap, R., 2003. Climate change scenarios and the effect of sea-level rise for Estonia. Global Planet. Change 36, 1-15. https://doi.org/10.1016/S09218181(02)00149-2.

Kouki, J., Arnold, K., Martikainen, P., 2004. Long-term persistence of aspen - a key host for many threatened species - is endangered in old-growth conservation areas in Finland. J. Nat. Conserv. 12 (1), 41-52. https://doi.org/10.1016/j.jnc.2003.08.002.

Kukumägi, M., Ostonen, I., Kupper, P., Truu, M., Tulva, I., Varik, M., Aosaar, J., Sõber, J., Lõhmus, K., 2014. The effects of elevated atmospheric humidity on soil respiration components in a young silver birch forest. Agric. For. Meteorol. 194, 167-174. https://doi.org/10.1016/j.agrformet.2014.04.003.

Kupper, P., Sõber, J., Sellin, A., Lõhmus, K., Tullus, A., Räim, O., Lubenets, K., Tulva, I., Uri, V., Zobel, M., Kull, O., Sõber, A., 2011. An experimental facility for free air humidity manipulation (FAHM) can alter water flux through deciduous tree canopy. Environ. Exp. Bot. 72 (3), 432-438. https://doi.org/10.1016/j.envexpbot.2010.09. 003.

Kuuluvainen, T., Penttinen, A., Leinonen, K., Nygren, M., 1996. Statistical opportunities for comparing stand structural heterogeneity in managed and primeval forests: an example from boreal spruce forest in southern Finland. Silva Fennica 30, 315-328. https://doi.org/10.14214/sf.a9243.

Lagomarsino, A., Lukac, M., Godbold, D.L., Marinari, S., De Angelis, P., 2013. Drivers of increased soil respiration in a poplar coppice exposed to elevated $\mathrm{CO}_{2}$. Plant Soil 362 (1-2), 93-106. https://doi.org/10.1007/s11104-012-1261-0.

Landhäusser, S.M., Pinno, B.D., Mock, K.E., 2019. Tamm review: seedling-based ecology, management, and restoration in aspen (Populus tremuloides). For. Ecol. Manage. 432, 231-245. https://doi.org/10.1016/j.foreco.2018.09.024.

Latif, Z.A., Blackburn, G.A., 2010. The effects of gap size on some microclimate variables during late summer and autumn in a temperate broadleaved deciduous forest. Int. J. Biometeorol. 54, 119-129. https://doi.org/10.1007/s00484-009-0260-1.

Latva-Karjanmaa, T., Penttilä, R., Siitonen, J., 2007. The demographic structure of European aspen (Populus tremula) populations in managed and old-growth boreal forests in eastern Finland. Can. J. For. Res. 37 (6), 1070-1081. https://doi.org/10. 1139/X06-289.

Liberloo, M., Calfapietra, C., Lukac, M., Godbold, D., Luo, Z.-B., Polle, A., Hoosbeek, M.R., Kull, O., Marek, M., Raines, C., Rubino, M., Taylor, G., Scarascia-Mugnozza, G., Ceulemans, R., 2006. Woody biomass production during the second rotation of a bioenergy Populus plantation increases in a future high $\mathrm{CO}_{2}$ world. Glob. Change Biol. 12 (6), 1094-1106. https://doi.org/10.1111/j.1365-2486.2006.01118.x.

Liesebach, M., Von Wuehlisch, G., Muhs, H.-J., 1999. Aspen for short-rotation coppice plantations on agricultural sites in Germany: Effects of spacing and rotation time on growth and biomass production of aspen progenies. For. Ecol. Manage. 121 (1-2), 25-39. https://doi.org/10.1016/S0378-1127(98)00554-4.

Lihavainen, J., Keinänen, M., Keski-Saari, S., Kontunen-Soppela, S., Sõber, A., Oksanen, E., 2016. Artificially decreased vapour pressure deficit in field conditions modifies foliar metabolite profiles in birch and aspen. J. Exp. Bot. 67 (14), 4367-4378. https://doi.org/10.1093/jxb/erw219.

Lindner, M., Fitzgerald, J.B., Zimmermann, N.E., Reyer, C., Delzon, S., van der Maaten, E., Schelhaas, M.-J., Lasch, P., Eggers, J., van der Maaten-Theunissen, M., Suckow, F., Psomas, A., Poulter, B., Hanewinkel, M., 2014. Climate change and European forests: what do we know, what are the uncertainties, and what are the implications for forest management? J. Environ. Manage. 146, 69-83. https://doi.org/10.1016/j.jenvman. 2014.07.030.

Lõhmus, K., Rosenvald, K., Ostonen, I., Kukumägi, M., Uri, V., Tullus, A., Aosaar, J., Varik, M., Kupper, P., Torga, R., Maddison, M., Soosaar, K., Sõber, J., Mander, Ü., Kaasik, A., Sõber, A., 2019. Elevated atmospheric humidity shapes the carbon cycle of a silver birch forest ecosystem: a FAHM study. Sci. Total Environ. 661, 441-448. https://doi.org/10.1016/j.scitotenv.2019.01.160.

McDonald, E.P., Kruger, E.L., Riemenschneider, D.E., Isebrands, J.G., 2002. Competitive status influences tree-growth responses to elevated $\mathrm{CO}_{2}$ and $\mathrm{O}_{3}$ in aggrading aspen stands. Funct. Ecol. 16, 792-801. https://doi.org/10.1046/j.1365-2435.2002. 00683.x.

McElhinny, C., Gibbons, P., Brack, C., Bauhus, J., 2005. Forest and woodland stand structural complexity: Its definition and measurement. For. Ecol. Manage. 218, 1-24. https://doi.org/10.1016/j.foreco.2005.08.034.

Metsaranta, J.M., Lieffers, V.J., 2010. Patterns of inter-annual variation in the size asymmetry of growth in Pinus banksiana. Oecologia 163, 737-745. https://doi.org/ 10.1007/s00442-009-1559-7.

Niglas, A., Kupper, P., Tullus, A., Sellin, A., 2014. Responses of sap flow, leaf gas exchange and growth of hybrid aspen to elevated atmospheric humidity under field conditions. AoB Plants 6, plu021. https://doi.org/10.1093/aobpla/plu021.

Niinemets, Ü., 2010. Responses of forest trees to single and multiple environmental stresses from seedlings to mature plants: past stress history, stress interactions, tolerance and acclimation. For. Ecol. Manage. 260, 1623-1639. https://doi.org/10. 1016/j.foreco.2010.07.054.

Oksanen, E., Lihavainen, J., Keinänen, M., Keski-Saari, S., Kontunen-Soppela, S., Sellin, A., Sõber, A., 2019. Northern forest trees under increasing atmospheric humidity. Prog. Bot. 80, 317-336. https://doi.org/10.1007/124_2017_15.

Orság, M., Fischer, M., Tripathi, A.M., Žalud, Z., Trnka, M., 2018. Sensitivity of short rotation poplar coppice biomass productivity to the throughfall reduction - estimating future drought impacts. Biomass Bioenerg. 109, 182-189. https://doi.org/10. 1016/j.biombioe.2017.12.028.

Parts, K., Tedersoo, L., Lõhmus, K., Kupper, P., Rosenvald, K., Sõber, A., Ostonen, I., 2013. Increased air humidity and understory composition shape short root traits and the colonizing ectomycorrhizal fungal community in silver birch stands. For. Ecol. Manage. 310, 720-728. https://doi.org/10.1016/j.foreco.2013.09.017.
Pontailler, J.Y., Ceulemans, R., Guittet, J., 1999. Biomass yield of poplar after five 2-year coppice rotations. Forestry 72 (2), 157-163.

Pretzsch, H., Dieler, J., 2011. The dependency of the size-growth relationship of Norway spruce (Picea abies [L.] Karst.) and European beech (Fagus sylvatica [L.]) in forest stands on long-term site conditions, drought events, and ozone stress. Trees Struct. Funct. 25 (3), 355-369. https://doi.org/10.1007/s00468-010-0510-1.

R Core Team, 2018. R: A language and environment for statistical computing. R Foundation for Statistical Computing, Vienna, Austria (http://www.R-project.org).

Rehfeldt, G.E., Ferguson, D.E., Crookston, N.L., 2009. Aspen, climate, and sudden decline in western USA. For. Ecol. Manage. 258, 2353-2364. https://doi.org/10.1016/j. foreco.2009.06.005.

Rosenvald, K., Tullus, A., Ostonen, I., Uri, V., Kupper, P., Aosaar, J., Varik, M., Sõber, J., Niglas, A., Rohula, G., Kukk, M., Sõber, A., Lõhmus, K., 2014. The effect of elevated air humidity on young silver birch and hybrid aspen biomass allocation and accumulation - acclimation mechanisms and capacity. For. Ecol. Manage. 330, 252-260. https://doi.org/10.1016/j.foreco.2014.07.016.

Rytter, L., 2006. A management regime for hybrid aspen stands combining conventional forestry techniques with early biomass harvests to exploit their rapid early growth. For. Ecol. Manage. 236, 422-426. https://doi.org/10.1016/j.foreco.2006.09.055.

Rytter, L., Rytter, R.M., 2017. Productivity and sustainability of hybrid aspen (Populus tremula $\mathrm{L} . \times P$. tremuloides Michx.) root sucker stands with varying management strategies. For. Ecol. Manage. 401, 223-232. https://doi.org/10.1016/j.foreco.2017. 07.020.

Schwinning, S., Weiner, J., 1998. Mechanisms determining the degree of size asymmetry in competition among plants. Oecologia 113 (4), 447-455. https://doi.org/10.1007/ s004420050397.

Sellin, A., Alber, M., Keinänen, M., Kupper, P., Lihavainen, J., Lõhmus, K., Oksanen, E., Sõber, A., Sõber, J., Tullus, A., 2017a. Growth of northern deciduous trees under increasing atmospheric humidity: possible mechanisms behind the growth retardation. Reg. Environ. Change 17 (7), 2135-2148. https://doi.org/10.1007/s10113-0161042-z.

Sellin, A., Alber, M., Kupper, P., 2017b. Increasing air humidity influences hydraulic efficiency but not functional vulnerability of xylem in hybrid aspen. J. Plant Physiol. 219, 28-36. https://doi.org/10.1016/j.jplph.2017.09.006.

Spinoni, J., Naumann, G., Vogt, J.V., 2017. Pan-European seasonal trends and recent changes of drought frequency and severity. Global Planet. Change 148, 113-130. https://doi.org/10.1016/j.gloplacha.2016.11.013.

Staudhammer, C.L., LeMay, V.M., 2001. Introduction and evaluation of possible indices of stand structural diversity. Can. J. For. Res. 31 (7), 1105-1115. https://doi.org/10. 1139/x01-033.

Strømme, C., Sivadasan, U., Nissinen, K., Lavola, A., Randriamanana, T., Julkunen-Tiitto, R., Nybakken, L., 2019. Interannual variation in UV-B and temperature effects on bud phenology and growth in Populus tremula. Plant Physiol. Biochem. 134, 31-39. https://doi.org/10.1016/j.plaphy.2018.08.029.

Sullivan, T.P., Sullivan, D.S., Lindgren, P.M.F., 2001. Stand structure and small mammals in young lodgepole pine forest: 10-year results after thinning. Ecol. Appl. 11, 1151-1173. https://doi.org/10.1890/1051-0761(2001) 011[1151:SSASMI]2.0. $\mathrm{CO} ; 2$.

Tullus, A., Rytter, L., Tullus, T., Weih, M., Tullus, H., 2012a. Short-rotation forestry with hybrid aspen (Populus tremula L. $\times$ P. tremuloides Michx.) in Northern Europe. Scand. J. For. Res. 27 (1), 10-29. https://doi.org/10.1080/02827581.2011.628949.

Tullus, A., Kupper, P., Sellin, A., Parts, L., Sõber, J., Tullus, T., Lõhmus, K., Sõber, A., Tullus, H., 2012b. Climate change at Northern latitudes: rising atmospheric humidity decreases transpiration, N-uptake and growth rate of hybrid aspen. PLoS One 7 (8). https://doi.org/10.1371/journal.pone.0042648. e42648.

Tullus, A., Kupper, P., Kaasik, A., Tullus, H., Lõhmus, K., Sõber, A., Sellin, A., 2017. The competitive status of trees determines their responsiveness to increasing atmospheric humidity - a climate trend predicted for northern latitudes. Glob. Change Biol. 23 (5), 1961-1974. https://doi.org/10.1111/gcb.13540.

Valladares, F., Laanisto, L., Niinemets, Ü., Zavala, M.A., 2016. Shedding light on shade: ecological perspectives of understorey plant life. Plant Ecolog. Divers. 9 (3), 237-251. https://doi.org/10.1080/17550874.2016.1210262.

Vanbeveren, S.P.P., Ceulemans, R., 2018. Genotypic differences in biomass production during three rotations of short-rotation coppice. Biomass Bioenerg. 119, 198-205. https://doi.org/10.1016/j.biombioe.2018.09.027.

Vanoni, M., Bugmann, H., Nötzli, M., Bigler, C., 2016. Quantifying the effects of drought on abrupt growth decreases of major tree species in Switzerland. Ecol. Evol. 6 (11), 3555-3570. https://doi.org/10.1002/ece3.2146.

Verlinden, M.S., Broeckx, L.S., Ceulemans, R., 2015. First vs. second rotation of a poplar short rotation coppice: above-ground biomass productivity and shoot dynamics. Biomass Bioenerg. 73, 174-185. https://doi.org/10.1016/j.biombioe.2014.12.012.

von Arx, G., Dobbertin, M., Rebetez, M., 2012. Spatio-temporal effects of forest canopy on understory microclimate in a long-term experiment in Switzerland. Agric. For. Meteorol. 166-167, 144-155. https://doi.org/10.1016/j.agrformet.2012.07.018.

von Wettberg, E.J., Weiner, J., 2003. Larger Triticum aestivum plants do not preempt nutrient-rich patches in a glasshouse experiment. Plant Ecol. 169, 85-92. https://doi. org/10.1023/A:1026253007056.

Wan, X., Landhäusser, S.M., Lieffers, V.J., Zwiazek, J.J., 2006. Signals controlling root suckering and adventitious shoot formation in aspen (Populus tremuloides). Tree Physiol. 26 (5), 681-687. https://doi.org/10.1093/treephys/26.5.681.

Weiner, J., Thomas, S.C., 1986. Size variability and competition in plant monocultures. Oikos 47 (2), 211-222. https://doi.org/10.2307/3566048.

Wichmann, L., 2001. Annual variations in competition symmetry in even-aged Sitka Spruce. Ann. Bot. 88, 145-151. https://doi.org/10.1006/anbo.2001.1445.

Worrall, J.J., Rehfeldt, G.E., Hamann, A., Hogg, E.H., Marchetti, S.B., Michaelian, M., Gray, L.K., 2013. Recent declines of Populus tremuloides in North America linked to 
climate. For. Ecol. Manage. 299, 35-51. https://doi.org/10.1016/j.foreco.2012.12. 033.

Worrell, R., 1995. European aspen (Populus tremula L.): a review with particular reference to Scotland I. Distribution, ecology and genetic variation. Forestry 68 (2), 93-105. https://doi.org/10.1093/forestry/68.2.93.

Worrell, R., Gordon, A.G., Lee, R.S., McInroy, A., 1999. Flowering and seed production of aspen in Scotland during a heavy seed year. Forestry 72 (1), 27-34. https://doi.org/ 10.1093/forestry/72.1.27.

Xue, L., Hagihara, A., 1999. Density effect, self-thinning and size distribution in Pinus densiflora Sieb. et Zucc. stands. Ecol. Res. 14 (1), 49-58. https://doi.org/10.1046/j. 1440-1703.1999.141284.x. 